\title{
PRODUCTIVITY OF PRODUCTION FACTORS \\ IN POLISH AGRICULTURE AND IN THE SELECTED \\ EUROPEAN UNION COUNTRIES WITH REGARD \\ TO THE COMMON AGRICULTURAL POLICY PAYMENTS
}

\author{
ANNA ŚCIUBEE
}

\begin{abstract}
The aim of the paper is to analyze the productivity of production factors of Polish and selected EU farms from 2004 to 2017, taking into account the Common Agricultural Policy (CAP) payments, based on the literature. In the postaccession period, there was a marked increase in the efficiency of production factors on Polish farms. The average land, labor, and capital productivity indices from 2004 to 2017 were EUR 442.89/ha, EUR 4,774.35/AWU, and EUR 0.25/ EUR 1, respectively. In 2014, land productivity increased to EUR 1,591.3/ha and labor productivity to EUR 11,800/AWU, amounting to $68.8 \%$ and $28.6 \%$ of the EU-28 average, respectively, while capital productivity was higher (EUR 1.41/EUR 1) compared to the EU-28 average (EUR 1.29/EUR 1). The share of CAP payments in the income of the Polish farms in 2014 increased to $49.5 \%$; however, this was still below the EU-28 average (61.1\%). Regardless of the fact that the total factor productivity (TFP) remains lower in comparison to other EU countries, the increased efficiency of Polish farms in the post-accession period should be considered as significant.
\end{abstract}

Keywords: productivity, production factors, CAP payments.

JEL codes: D24, O13, Q12.

Anna Ściubet, BEng, MSc, Institute of Agricultural and Food Economics - National Research Institute, Department of Agricultural Accountancy; ul. Świętokrzyska 20, 00-002 Warsaw, Poland (Anna.Sciubel@ierigz.waw.pl). ORCID iD: 0000-0003-3960-6483. 


\section{Introduction}

In the post-war period, the basic task of European agriculture was to guarantee food self-sufficiency for society. The countries forming the European Coal and Steel Community (1951), which then became the European Economic Community (1958), pursued an independent policy of supporting agriculture, which consisted mainly in applying guaranteed high prices to agricultural products without limiting the volume of their production. A need to give the agricultural economy Community status was the basis for establishing, in 1962, the Common Agricultural Policy - CAP (European Parliament, 2020c). The CAP priorities remained, invariably, the following specific objectives adopted in the Treaty of Rome (1958) (European Parliament, 2020a):

- increasing the agricultural productivity by promoting technical progress and making optimal use of production factors, in particular the labor force;

- providing a decent standard of living for farmers;

- stabilization of markets;

- guaranteeing security of supplies;

- providing reasonable prices for consumers.

As a result of the reforms carried out during the more than fifty years of the CAP's existence, measures allowing for the achievement of the above-mentioned objectives have been developed, structured in two pillars. The first pillar mainly includes direct payments aimed at supporting agricultural income (the majority of CAP funds). In the second pillar, funds are mainly used to implement the rural development program and are allocated to countries or regions characterized by a lower level of agricultural development compared to the EU average. However, determining the effects of support from these pillars is hindered by the multi-vector impact of various factors and the insufficient number of studies, often covering comparative periods that are too short (Pawłowski and Czubak, 2018). Most studies focus on the efficiency of using total CAP payments on farms (Zhu and Lansink, 2010; Latruffe and Desjeux, 2016; Czyżewski and Staniszewski, 2016), while few identify the first and the second pillar of the CAP (Rizov, Pokrivcak and Ciaian, 2013; Dudu and Kristkova, 2017).

The aim of the paper is to show how the productivity of production factors of Polish farms evolved from 2004 to 2017 against the background of EU farms from other countries, based on the available literature on the topic. The article also takes into account the impact of payments under the first and second pillar of the CAP on the productivity of production factors in Poland and in the EU.

\section{Measures to support farms under the first and the second pillar of the CAP}

Losses suffered by agricultural producers due to the limitation and modification of market interventions and the reduction in export subsidies as a result of the MacSharry reform (1992) were offset by the introduction of a direct payment per unit of cultivation area (crop production) or by a bonus dependent on the cattle popula- 
tion (livestock production). In the subsequent CAP reforms (1999-2013), payments were decoupled, making farmers oriented towards the needs of the market and consumers (European Parliament, 2020c). The tasks carried out under the first pillar of the common agricultural policy were financed entirely by the EU, as part of which, in addition to the common organization of agricultural markets, direct payments to farmers were ring-fenced. The common organization of agricultural markets is currently less important (1.6\% of CAP funds in 2020) and mainly covers market interventions in the event of serious disturbances in the agricultural sector (European Parliament, 2020d). On the other hand, direct payments to farmers form a basic payment scheme (25.6\% of CAP funds in 2020) including three mandatory payments: basic payment per ha, greening payment and additional payment for young farmers and four other optional payments: distribution payment, support for areas with natural constraints, support for economic or social reasons, and support for small farms (European Parliament, 2020e).

New challenges related to implementing the extensive Environmental Program adopted (Agenda 2000) are reflected in the establishment of (2005) the second pillar of the Common Agricultural Policy, covering the rural development policy. The basic objective of the second pillar of the CAP is to promote and support sustainable development in rural areas (8.1\% of CAP funds in 2020) by implementing the following priorities: knowledge transfer; enhancing the competitiveness, viability, and sustainability of farms; organizing the food chain and risk management; protecting and restoring ecosystems dependent on agriculture; rational management of natural resources and preventing climate change (agri-environment-climate measures); and promoting economic development and social inclusion (European Parliament, 2020f). The European Agriculture Guidance and Guarantee Fund (EAGGF), in operation since 1962, was replaced (2005) by the European Agricultural Guarantee Fund (EAGF) aimed at financing expenses from the first pillar of the CAP (Common organization of agricultural markets and direct payments to farmers) and the European Agricultural Fund for Rural Development (EAFRD) for financing the second pillar of the CAP (Rural Development Policy). Expenses for the Common Agricultural Policy were gradually reduced and significantly decreased from $0.54 \%$ of EEC gross income (1990) to $0.34 \%$ of EU gross income (34.5\% of the budget) in 2020 (European Parliament, 2020b). From 2014 to 2020, the funds of the first pillar (EUR 308.7 billion) and of the second pillar (EUR 99.6 billion) accounted for $75.6 \%$ and $24.4 \%$ of CAP funds, respectively (European Parliament, 2020b).

\section{Farm productivity indices}

The common agricultural policy programs applicable in the EU Member States are implemented within a specific timeframe and are subject to adjustments or modifications according to needs (verification of the objectives set). Involving significant amounts of money requires monitoring and assessing their impact on agriculture in the individual EU countries. The main indicator for assessing the level of agriculture used in the EU countries is farm productivity (economic relationship 
determining outputs achieved in relation to expenditures incurred) most often expressed by the land productivity index, the labor productivity index, and the capital productivity index, or the total factor productivity index = TFP (Grotkiewicz and Michałek, 2009a; 2009b; Buks, Floriańczyk and Toczyński, 2011). Land productivity (ratio of the outputs to the utilized agricultural area $=$ PLN $/$ ha) is determined mainly by climatic and soil factors of a farm, agricultural technology, the level of fertilization, and the degree of plant protection. Labor productivity (ratio of the outputs to the number of persons employed $=$ PLN/person) mainly reflects the structure of crops and the farm's production volume, its degree of mechanization, and qualifications of the labor force (human factor). Capital productivity (ratio of the outputs to the amount of capital invested) points to the degree of efficiency of using financial investments in the farm's production processes. On the other hand, total factor productivity (TFP) is the ratio of total output to total inputs and is estimated using complex regression analysis equations and multi-stage logarithmic mathematical models taking into account partial, integral manufacturing factors, i.e. land productivity, labor productivity, and capital productivity and their interaction (Goraj and Mańko, 2011; Rizov et al., 2013; Czyżewski and Staniszewski, 2016; Jin and Huffman, 2016). Therefore, these indices include the most important components determining the level of productive forces having a significant impact on the economic performance of each farm.

The assessment of farm efficiency on a macroeconomic scale, allowing for a comparison of results among countries, is carried out based on the European Accounts for Agriculture (EAA) published by Eurostat, and on a microeconomic scale (analysis of national results) on the basis of FADN data collected in the Farm Accountancy Data Network (Zawalińska, Majewski, and Wąs, 2015). The results of the macroeconomic analysis mainly serve to comparatively assess the efficiency of agricultural sectors at the EU level, while the results of the microeconomic analysis make it possible to determine differences occurring at the level of types and specializations of farms functioning in the individual EU countries. Moreover, the implementation of agri-environmental policy requires indices for assessing the climate and environmental impact of the agricultural production (Buks et al., 2011) to be included in methods for analyzing farm performance.

\section{Productivity of production factors in Polish agriculture of and in the selected $\mathbf{E U}$ countries}

Polish agriculture making use of payments in the first financial framework (2004-2006) was characterized by significantly lower - when compared to the highestranked EU countries (Michałek, Grotkiewicz, and Peszek, 2009) - both the average land productivity index (Poland - USD 961/ha, while France - USD 1,673/ha, the Netherlands - USD 7,224/ha, Germany - USD 1,532/ha) and the labor productivity index (Poland - USD 3,914/person, while France - USD 70,212/person, the Netherlands - USD 64,953/person, Germany - USD 32,422/person). The increase in capital expenditures from PLN 2.4 billion in 2005 to PLN 3.6 billion in 
2007 made it possible, in addition to the favorable area restructuring of agriculture (Baer-Nawrocka and Poczta, 2016), to better equip farms with modern equipment (direct payments under the first pillar and multi-functional payments under the second pillar of the CAP), which had a particularly positive impact on labor productivity (Baer-Nawrocka and Poczta, 2018).

Between 2004 and 2007, labor productivity reached already $32-45 \%$ of the average value of the same index for the EU, although the amount of all subsidies at that time was only about $30 \%$ of the average subsidies of the EU countries (Sobczyński, 2010). The biggest beneficiaries were large farms (third and fourth economic size class, 8-40 ESU), in which the labor productivity index was closest to the EU average and amounted to $75.70 \%$ and $70.26 \%$ of the value in the EU countries, respectively (the analysis did not take into account small farms characteristic of Poland; economic size class $<8 \mathrm{ESU}$ ). In the period which was already partially covering the second financial framework (2004-2009), the average labor productivity index (PLN 8,920/person) was higher when compared to the pre-accession period (1998-2003 ) by $35.5 \%$, contributing to a reduction in the employment rate in agriculture by around $8 \%$ (Gołaś, 2010).

The integration of Poland with the EU made it possible for agriculture, by 2009 , to achieve an income increase of about $14 \%$, which resulted in $41 \%$ from EU subsidies (Gołaś, 2010). Other studies (Jóźwiak, Mirkowska, and Ziętara, 2018) confirm a further increase in labor productivity on Polish farms (positive correlation with the utilized agricultural area), i.e. from EUR 7.1 thousand $\mathrm{SO}^{1 / p e r s o n}$ in 2005 to EUR 15.2 thousand SO/person in 2016. However, the index obtained was 7.7 times lower when compared to the average (EUR 116.8 thousand $\mathrm{SO} /$ person) of the 15 "old" EU members.

Increased land and labor productivity on Polish farms was also positively translated into income earned by farmers. Positive changes were confirmed by an analysis of the income of farms making use of EU subsidies during the two financial frameworks covering 2004-2013 (Zawalińska et al., 2015). In that period, with large differences among the Member States, the identified income growth rate in domestic agriculture was higher than in the so-called "old" EU countries. Average income per FTE on a farm increased from EUR 2,432 in 2005 to EUR 4,113 in 2013 and amounted to around $30 \%$ of the EU-28 average, i.e. EUR 12,591. The authors of the study state that in 2012 the highest increase in income per ha was achieved by farms involved in the crop production $(2,661 \mathrm{PLN} / \mathrm{ha})$ and farms specializing in cattle breeding $(2,174 \mathrm{PLN} / \mathrm{ha})$, and the number of persons employed in agriculture decreased from 15.0 million (2000) to 13.7 million in 2013. According to Zabolotnyy, Felczak, and Wasilewski (2018), between 2005 and 2013 the increased labor efficiency had a greater impact on revenues generated by Polish farms than an increase in the use of capital and land factors.

\footnotetext{
${ }^{1}$ Standard Output (SO) is an average 5-year value of production of a specific agricultural activity (crop or livestock) obtained from 1 ha or from 1 animal (exclusive of: edible mushrooms $-100 \mathrm{~m}^{2}$, poultry -100 head, bees -1 beehive, i.e. 1 bee family) within 1 year, in average production conditions for a given region.
} 
In other national studies covering 2004-2012 (Grochowska and Mańko, 2014), it was found that an increase in the total productivity (TFP) of the analyzed types of commodity farms (crop production, dairy farming, pig farming, mixed production farms) was, just like in the so-called "old" EU countries, significantly differentiated. Farms specializing in dairy farming had the highest TFP growth rate $(1.90 \%)$, while the lowest rate was characteristic of farms involved in crop production (1.04\%). The TFP index calculated for farms rearing pigs was $1.13 \%$ and for farms with mixed production it was $1.45 \%$. In estimating the components of the TFP, the authors of the study state that a high increase in the land productivity and labor productivity indices was characteristic of farms involved in crop production $(0.42 \%$ and $0.52 \%$, respectively) and farms with mixed production $(0.44 \%$ and $0.34 \%$, respectively). The highest and similar use of capital was found on farms rearing dairy cattle $(0.59 \%)$ and pigs $(0.56 \%)$.

An increase of all three production factors in Polish agriculture was found in the study (Smędzik-Ambroży, Rutkowska, and Kirbas, 2019) covering 2004-2017. In that period, the average land, labor, and capital productivity on Polish farms was EUR 442.89/ha, EUR 4,774.35/AWU2 ${ }^{2}$, EUR 0.25 , respectively, and was significantly lower than the average value of the same indices (excluding capital productivity in the Netherlands) in the countries with high levels of agriculture: in the Netherlands (EUR 10,712.55/ha; EUR 140,442.91/AWU, and EUR 0.24, respectively), Germany (EUR 2,285.05/ha; EUR 86,822.63/AWU, and EUR 0.31, respectively), and France (EUR 1,795.65/ha, EUR 75,554.96/AWU, and EUR 0.72, respectively). The share of EU payments in the income of Polish farms increased to $49.5 \%$ in 2014, but was still lower than the average value (61.1\%) (Baer-Nawrocka and Poczta, 2016).

When compared to the other EU-28 countries, Polish agriculture was still characterized (2015-2017) by the several times lower TFP index and was ahead only of Croatia (Smędzik-Ambroży et al., 2019). The authors of the papers (Baer-Nawrocka and Poczta, 2016; Smędzik-Ambroży et al., 2019) express the opinion that a further increase in the productivity of domestic agriculture is a prerequisite for maintaining the competitiveness of the entire agricultural sector in Poland.

On economically strong farms in Germany, the Netherlands, and Sweden, specializing in the crop production, the impact of EU subsidies (1995-2004) had no significant impact on the productivity of production factors (Zhu and Lansink, 2010). Similar relations were also demonstrated in the case of analyzing French farms (1999-2006) involved in the crop production and in breeding dairy cattle and beef cattle (Latruffe and Desjeux, 2016). In turn, Czyżewski and Smędzik-Ambroży (2017), when analyzing the level of the crop production (yields) and livestock production (milk, pork) in the 24 EU countries, showed (2007-2012) that an average annual increase in the total factor productivity (TFP) was between 0.7 and $1.3 \%$. In other studies (Fuglie, 2015), the TFP index calculated for the EU countries of the Northern and Southern regions (2001-2012) stood at $1.44 \%$ and $1.92 \%$,

${ }^{2}$ AWU (Annual Work Unit) - the annual work unit per FTE, amounting to 2,120 hours a year in agriculture. 
respectively, confirming significant differences in the TFP among the regions of Europe. In the period preceding the introduction of the second pillar of the CAP, in the 15 analyzed Western European countries, a negative impact of other forms of payments on the farm productivity was found, while after the implementation $(2005 / 2006)$ of the second pillar, only some countries saw an upward trend. In the whole analyzed period covering 1990-2008, the TFP index calculated for various types of farms ranged from $0.73 \%$ (Greece) to $1.67 \%$ (Finland) and average annual TFP changes ranged from $-0.78 \%$ in Finland to $2.05 \%$ in Italy (Rizov et al., 2013). The lack of a favorable impact of payments from the first and second pillar on the productivity of French farms involved in crop production was also demonstrated by Mary in his studies (2013). Moreover, the author concluded that coupled payments and payments to areas with natural constraints had a negative impact on the TFP index (each EUR 100 resulted in a $0.02 \%$ reduction in the TFP). In turn, Garrone, Emmers, Olper, and Swinnen (2018), who analyzed the functioning of CAP payments for 2004-2014 in 27 EU countries, demonstrated a negative impact of payments from the first pillar on labor productivity and a positive impact in the case of payments from the second pillar of the CAP. It is therefore reasonable to further analyze integral factors of production and the structure of the origin of payments in the process of assessing the productivity of farms.

In the case of the measures implemented under the second pillar of the CAP, Schroeder, Gocht, and Britz (2015) found that payments from this pillar had a positive impact amounting to $0.15 \%$ on the use of extensively used land (grassland), increasing the income of farms producing beef cattle by $5 \%$. One of the few national studies attempting to assess the implementation of the second pillar of the CAP in the Central and Eastern European countries (2007-2013) did not find a close and unambiguous link between payments from the RDP and effective use of the means of production and changes in family farm income (Pawłowski and Czubak, 2018). The authors of the study attribute this fact to a long-term impact of funds under the second pillar going beyond the period analyzed. The most comprehensive analysis of the agricultural productivity in the EU countries making use of payments under the second pillar of the CAP between 2007 and 2013 can be found in the study by Dudu and Kristkova (2017). The mathematical model used four categories of financial support (payments supporting human capital, payments supporting technical progress, agri-environmental payments and rural development payments). A statistically significant impact of payments dedicated directly to rural development on an increase in the total factor productivity index (TFP) was not found in any analyzed EU country, while the results suggested only an increase in the TFP in European regions receiving relatively high agri-environmental payments and payments supporting human capital and technical progress, i.e. RDP funds allowing for the development of farms.

Based on the results of the studies, it can be concluded that possibilities of increasing the agricultural productivity in the Western European countries are limited due to the already high satisfactory productivity of production facors. On the other 
hand, in the use of production factors of domestic agriculture, there are still significant reserves which may be used in the event of progressive further restructuring of farms. Favorable changes in the agrarian structure of farms should result in the better use of rural development program (RDP) funds enabling an increase in capital expenditures (modernization, construction of livestock and production facilities, technical equipment) in all types of farms. Furthermore, taking into account further biotechnological achievements (innovation) in agriculture, it can be assumed that there are potential conditions for achieving a higher total production index, leading, with a stabilization of or reduction in unit costs, to a more efficient use of production factors (land, labor, capital), particularly on farms functioning in areas with lower levels of agricultural development (Grotkiewicz and Michałek, 2009a; 2009b; Baer-Nawrocka and Poczta, 2018). However, it is not always the case where the achievement of the objectives set in rural development program (allocation of increased funds for the environmental protection) may have a positive impact on the production factor indices or on achieving measurable economic benefits by farmers. In achieving the objectives of the CAP, the level of direct payments (first pillar) is associated with an obligation for farmers to carry out certain tasks to improve agri-environmental conditions (second pillar). However, meeting these requirements, even if only in relation to the so-called "greening", could result, in the very area of the Baltic States (including Poland), in reducing the area of main crops, increasing prices of products, and reducing the livestock population, thus leading to a reduction in farmers' income (Wąs et al., 2014). In order to achieve the objectives specified in the rural development program, it is therefore necessary to provide farmers with additional financing (increasing the share of the second pillar in the total CAP fund) and to launch further possibilities of obtaining income also from additional sources (Wąs et al., 2018). Furthermore, the CAP requirements regarding rational management of natural resources and the transition to the low-carbon economy (reduction in the intensive production) also point to a need to develop family sustainable farms involved both in the crop and livestock production (care for the environment and the maintenance of high quality of products) and in providing services to society (Buks et al., 2011; Czyżewski and Stępień, 2017; Majewski and Malak-Rawlikowska, 2018).

\section{Conclusions}

Based on the available publications, it can be concluded that the direct payments in the first pillar of the CAP allowed EU farmers to increase their income, but had no statistically significant impact on increasing the total factor productivity (TFP); in the case of certain integral indices (e.g. labor productivity), this impact was even negative. According to the results of the studies taking into account the second pillar of the CAP, the payments directly dedicated to rural development also did not result in a statistically significant increase in the TFP in EU countries. Regardless of the still lower average TFP index in Poland compared to other EU countries, an increase in farm efficiency in the post-accession period cannot be disputed. 
Between 2004 and 2017, the average land, labor, and capital productivity indices on Polish farms were EUR 442.89/ha, EUR 4,774.35/AWU, and EUR 0.25/ EUR 1, respectively. In 2014, land productivity reached EUR 1,591.3 ha, and labor productivity reached EUR $11,800 / \mathrm{AWU}$, amounting to $68.8 \%$ and $28.6 \%$ of the EU-28 average, respectively, while capital productivity (EUR 1.41/EUR 1) was above the EU-28 average (EUR 1.29/EUR 1). The share of CAP payments in the income of Polish farms in 2014 increased to $49.5 \%$ and was below the EU-28 average $(61.1 \%)$.

A comprehensive assessment of the productivity of production factors on Polish farms making use of CAP payments in the full post-accession period (2004-2020) requires further research. 


\section{References}

Baer-Nawrocka, A., Poczta, W. (2016). Polskie rolnictwo na tle rolnictwa Unii Europejskiej. In: J. Wilkin, I. Nurzyńska (eds.), Polska wieś 2016. Raport o stanie wsi (pp. 81-106). Warszawa: Wydawnictwo Naukowe SCHOLAR.

Baer-Nawrocka, A., Poczta, W. (2018). Rolnictwo polskie - przemiany i zróżnicowanie regionalne. In: J. Wilkin, I. Nurzyńska (eds.), Polska wieś 2018. Raport o stanie wsi (pp. 87-109). Warszawa: Wydawnictwo Naukowe SCHOLAR.

Buks, J., Floriańczyk, Z., Toczyński, T. (2011). Zagadnienia produktywności $w$ strategiach rozwoju i jej pomiar w odniesieniu do gospodarstw zrównoważonych. Program Wieloletni 2011-2014, No. 27. Warszawa: IERiGŻ-PIB.

Czyżewski, B., Smędzik-Ambroży, K. (2017). The Regional Structure of the CAP Subsidies and the Factor Productivity in Agriculture in the EU 28. Agricultural Economics - Czech, 63, pp. 149-163.

Czyżewski, A., Stępień, S. (2017). Nowe uwarunkowania ekonomiczne wspólnej polityki rolnej (WPR) Unii Europejskiej. Ekonomista, No. 6, pp. 675-697. Retrieved from: http://www. ekonomista.info.pl (access date: 22.09.2020).

Czyżewski, A., Staniszewski, J. (2016). Zastosowanie regresji panelowej dla oceny produktywności i dochodowości w rolnictwie krajów Unii Europejskiej po 2005 roku. Roczniki Naukowe Ekonomii Rolnictwa i Rozwoju Obszarów Wiejskich, Vol. 103, Issue 3, pp. 7-21.

Dudu, H., Kristkova, Z.S. (2017). Impact of CAP Pillar II Payments on Agricultural Productivity. European Commission, JRC Technical Reports, 1-30.

European Parliament (2020a). Noty tematyczne o Unii Europejskiej. Wspólna Polityka Rolna (WPR) a Traktat. Retrieved from: https://www.europarl.europa.eu/factsheets/pl/sheet/103/ wspolna-polityka-rolna-wpr-a-traktat (access date: 14.07.2020).

European Parliament (2020b). Noty tematyczne o Unii Europejskiej. Finansowanie WPR. Retrieved from: https:/www.europarl.europa.eu/factsheets/pl/sheet/106/finansowanie-wpr (access date: 14.07.2020).

European Parliament (2020c). Noty tematyczne o Unii Europejskiej. Instrumenty WPR i ich reformy. Retrieved from: https://www.europarl.europa.eu/factsheets/pl/sheet/107/instrumenty-wpr-i-ich-reformy (access date: 14.07.2020).

European Parliament (2020d). Noty tematyczne o Unii Europejskiej. Pierwszy Filar Wspólnej Polityki Rolnej (WPR): I-Wspólna Organizacja Rynków Produktów Rolnych. Retrieved from: https://www.europarl.europa.eu/factsheets/pl/sheet/108/pierwszy-filar-wpr-i-wspolna-organizacja-rynkow-produktow-rolnych-worr- (access date: 14.07.2020).

European Parliament (2020e). Noty tematyczne o Unii Europejskiej. Pierwszy Filar Wspólnej Polityki Rolnej (WPR): II-Płatności bezpośrednie dla rolników. Retrieved from: https:// www.europarl.europa.eu/factsheets/pl/sheet/109/pierwszy-filar-wspolnej-polityki-rolnej-wpr-ii-platnosci-bezposrednie-dla-rolnik (access date: 14.07.2020).

European Parliament (2020f). Noty tematyczne o Unii Europejskiej. Drugi Filar WPR: Polityka Rozwoju Obszarów Wiejskich, 2020. Retrieved from: https://www.europarl.europa.eu/factsheets/pl/sheet/110/drugi-filar-wpr-polityka-rozwoju-obszarow-wiejskich (access date: 14.07.2020).

Fuglie K. (2015). Accounting for Growth in Global Agriculture. Bio-Based and Applied Economics, 4(3), pp. 201-234.

Garrone, M., Emmers, D., Olper, A., Swinnen, J. (2018). Studies on Agricultural Productivity: CAP Payments and Labour Productivity (Convergence) in EU Agriculture. LICOS Discussion Paper, No. 409, 1-38. Retrieved from: http://www.econ.kuleuven.be/licos (access date: 24.09.2020). 
Gołaś, S. (2010). Wydajność i dochodowość pracy w rolnictwie w świetle rachunków ekonomicznych dla rolnictwa. Zagadnienia Ekonomiki Rolnej, No. 3(324), pp. 19-42.

Goraj, L., Mańko, S. (2011). Model szacowania pełnych kosztów działalności gospodarstw rolnych. Zagadnienia Ekonomiki Rolnej, No. 3(328), pp. 28-58.

Grochowska, R., Mańko, S. (2014). Produktywność gospodarstw rolnych w Polsce na tle innych krajów. Zeszyty Naukowe Ekonomiki Rolnej SGGWw Warszawie. Problemy Rolnictwa Światowego, Vol. 29, Issue 4, pp. 25-33.

Grotkiewicz, K., Michałek, R. (2009a). Ocena poziomu produkcyjności i wydajności w rolnictwie na przykładzie wybranych regionów Polski. Inżynieria Rolnicza 6(115), pp. 103-108.

Grotkiewicz, K., Michałek, R. (2009b). Postęp naukowo-techniczny a wydajność ziemi i pracy w rolnictwie. Inżynieria Rolnicza 6(115), pp. 109-115.

Jin, Y., Huffman, W.E. (2016). Measuring Public Agricultural Research and Extension and Estimating Their Impactsz on Agricultural Productivity: New Insights from U.S. Evidence. Agricultural Economics, 47, pp. 15-31.

Józwiak, W., Mirkowska, Z., Ziętara, W. (2018). Rola dużych gospodarstw rolnych we wzroście produktywności pracy rolnictwa polskiego na tle sytuacji w innych wybranych krajach Unii Europejskiej. Roczniki Naukowe Ekonomiki Rolnictwa i Rozwoju Obszarów Wiejskich, Vol. 105, Issue 1, pp. 32-46.

Latruffe, L., Balcombe, K., Davidova, S., Zawalińska, K. (2004). Determinants of Technical Efficiency of Crop and Livestock Farms in Poland. Applied Economics, Vol., 36, No. 12, pp. 1255-1263.

Latruffe, L., Desjeux, Y. (2016). Common Agricultural Policy Support, Technical Efficiency and Productivity Change in French Agriculture. Review of Agricultural, Food and Environmental Studies, 97, pp. 15-28.

Majewski, E., Malak-Rawlikowska, A. (2018). Scenariusze Wspólnej Polityki Rolnej po 2020 roku. Zagadnienia Ekonomiki Rolnej / Problems of Agricultural Economics, No. 1(354), pp. 9-38.

Mary, S. (2013. Assessing the Impacts of Pillar I and II Subsidies on TFP in French Crop Farms. Journal of Agricultural Economics, Vol., 64, Issue 1, pp. 133-144.

Michałek, R., Grotkiewicz, K., Peszek, A. (2009). Wydajność pracy i ziemi w wybranych krajach Unii Europejskiej. Inżynieria Rolnicza, 1(110), pp. 199-2004.

Pawłowski, K.P., Czubak, W. (2018). Identyfikacja sposobów implementacji II filaru WPR w krajach Europy Środkowo-Wschodniej. Zeszyty Naukowe SGGW. Ekonomika i Organizacja Gospodarki Żywnościowej, No. 124, pp. 109-123.

Rizov, M., Pokrivcak, J., Ciaian, P. (2013). CAP Subsidies and Productivity of the EU Farms. Journal of Agricultural Economics, Vol. 64, No. 3, pp. 537-557.

Schroeder, L.A., Gocht, A., Britz, W. (2015). The Impact of Pillar II Funding: Validation from a Modeling and Evaluation Perspective. Journal of Agricultural Economics, Vol., 66, Issue 2, pp. 415-441.

Smędzik-Ambroży, K., Rutkowska, M., Kirbas, H. (2019). Productivity of the Polish Agricultural Sector Compared to European Member States in 2004-2017 Based on FADN Farms. Annals of the Polish Association of Agricultural and Agribusiness Economists, Vol. 21, No. 3, pp. 422-431.

Sobczyński, T. (2010). Wydajność pracy a poziom wsparcia gospodarstw rolniczych w Polsce na tle UE. Roczniki Nauk Rolniczych, Serie G, Vol. 97, Issue 3, pp. 244-257.

Wąs, A., Zawalińska, K., Britz, W. (2014). Impact of "Greening” the Common Agricultural Policy on Sustainability of European Agriculture: from Perspective of the Baltic Sea Countries. Journal of Agribusiness and Rural Development, 4(34), pp. 191-212. 
Wąs, A., Malak-Rawlikowska, A., Majewski, E. (2018). The New Delivery Model of the Common Agricultural Policy After 2020 - Challenges for Poland. Zagadnienia Ekonomiki Rolnej / Problems of Agricultural Economics, No. 4(357), pp. 33-59.

Zabolotnyy, S., Felczak, T., Wasilewski, M. (2018). Zależności między efektywnością wykorzystania zasobów wytwórczych a sytuacją finansową przedsiębiorstw rolniczych. Zagadnienia Ekonomiki Rolnej / Problems of Agricultural Ekonomics, 2(355), pp. 41-60.

Zawalińska, K., Majewski, E., Wąs, A. (2015). Długookresowe zmiany w dochodach z polskiego rolnictwa na tle krajów Unii Europejskiej. Roczniki Naukowe SERiA, Vol. XVII, Issue 6, pp. 346-354.

Zhu, X., Lansink, A.O. (2010). Impact of CAP Subsidies on Technical Efficiency of Crop Farms in Germany, the Netherlands and Sweden. Journal of Agricultural Economics, Vol. 61, No. 3, pp. 545-564. 


\title{
PRODUKTYWNOŚĆ CZYNNIKÓW PRODUKCJI W ROLNICTWIE POLSKI I W WYBRANYCH KRAJACH UNII EUROPEJSKIEJ Z UWZGLĘDNIENIEM PŁATNOŚCI WSPÓLNEJ POLITYKI ROLNEJ
}

\begin{abstract}
Abstrakt
Celem artykutu jest przedstawienie na podstawie literatury przedmiotu kształtowania się produktywności czynników produkcji w krajowych gospodarstwach rolnych oraz wybranych gospodarstwach unijnych w latach 2004-2017, z uwzględnieniem płatności ze wspólnej polityki rolnej. Wykazano, że w okresie poakcesyjnym nastapiło wyraźne zwiększenie efektywności wykorzystania czynników produkcji w gospodarstwach polskich. Średnia wartość wskaźnika wydajności ziemi, pracy i kapitatu krajowych gospodarstwach rolnych w latach 2004-2017 wynosita odpowiednio: 442,89 EUR/ha, 4 774,35 EUR/AWU i 0,25 EUR/1 EUR. W 2014 roku wydajność ziemi osiagnęła wartość 1 591,3 EUR/ha, wydajność pracy 11800 EUR/AWU, stanowiac odpowiednio 68,8 i 28,6\% średniego poziomu $w$ UE-28, natomiast wydajność kapitału (1,41 EUR/1EUR) była wyższa od średniej wartości (1,29 EUR/1 EUR) 28 krajów unijnych. W 2014 roku udziat płatności wspólnej polityki rolnej (WPR) w dochodzie krajowych gospodarstw rolnych wzróst do 49,5\% nie osiagając jednak średniej wartości $(61,1 \%)$ analogicznego wskaźnika notowanego w UE-28. Niezależnie od ciagle niższego w porównaniu z krajami UE wskaźnika całkowitej produktywności wszystkich czynników produkcji (TFP) wzrost efektywności krajowych gospodarstw rolnych w okresie poakcesyjnym należy uznać za istotny.
\end{abstract}

Słowa kluczowe: produktywność, czynniki produkcji, płatności WPR.

Accepted for print: 15.03.2021.

Unless stated otherwise all the materials on the website are available under the Creative Commons Attribution 4.0 International license.

Some rights reserved to the Institute of Agricultural and Food Economics - National Research Institute.

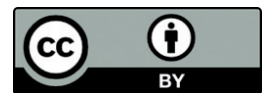

